Royal Netherlands Institute for Sea Research

This is a postprint of:

Svensson, E., Schouten, S., Stam, A., Middelburg, J.J. \& Sinninghe Damsté, J.S. (2015). Compound-specific stable isotope analysis of nitrogen-containing intact polar lipids. Rapid Communications in Mass Spectrometry, 29(23), 2263-2271

Published version: $\underline{\mathrm{dx} . \text { doi.org/10.1002/rcm.7393 }}$

Link NIOZ Repository: $\underline{w w w . v l i z . b e / n l / i m i s ? m o d u l e=r e f \& r e f i d=250882 ~}$

[Article begins on next page]

The NIOZ Repository gives free access to the digital collection of the work of the Royal Netherlands Institute for Sea Research. This archive is managed according to the principles of the Open Access Movement, and the Open Archive Initiative. Each publication should be cited to its original source - please use the reference as presented.

When using parts of, or whole publications in your own work, permission from the author(s) or copyright holder(s) is always needed. 


\section{Compound-specific stable isotope analysis of nitrogen- containing intact polar lipids}

\section{Elisabeth Svensson ${ }^{\mathrm{a}, \mathrm{c} *}$, Stefan Schouten ${ }^{\mathrm{a}, \mathrm{b} *}$, Axel Stam ${ }^{\mathrm{a}}$, Jack J. Middelburg b, Jaap S. Sinninghe Damstéa,b}

a Department of Marine Organic Biogeochemistry, NIOZ Royal Netherlands Institute for Sea Research

P.O. Box 59, 1790 AB Den Burg (Texel), The Netherlands

E-mails: esvensson@pitt.edu, stefan.schouten@nioz.nl, jaap.damste@nioz.nl

b Department of Earth Sciences, Faculty of Geosciences, Utrecht University, PO Box 80021, 3508 TA Utrecht, The Netherlands

E-mail: j.b.m.middelburg@uu.nl

c Present address: Department of Geology \& Planetary Science, University of Pittsburgh, Pittsburgh, PA 15260, USA.

*Corresponding authors

Keywords: nitrogen isotopes, intact polar lipids, compound-specific isotope analysis, bacteria, biosynthesis

\section{RATIONALE}

Compound specific isotope analysis (CSIA) of nitrogen in amino acids has proven a valuable tool in many fields (e.g. ecology). Several intact polar lipids (IPLs) also contain nitrogen, and their nitrogen isotopes have the potential to elucidate food-web interactions or metabolic pathways. Here we have developed novel methodology for the determination of $\delta^{15} \mathrm{~N}$ values of nitrogen-containing headgroups of IPLs using gas chromatography coupled with isotope ratio mass spectrometry.

\section{METHODS}

Intact polar lipids with nitrogen-containing headgroups were hydrolyzed and the resulting compounds were derivatized by 1) acetylation with pivaloyl chloride for compounds with amine and hydroxyl groups or 2) esterification using acidified 2-propanol followed by acetylation with pivaloyl chloride for compounds with both carboxyl and amine groups. The $\delta^{15} \mathrm{~N}$ values of derivatives were subsequently determined using gas chromatography/combustion/isotope-ratio mass spectrometry.

\section{RESULTS}

Intact polar lipids with ethanolamine and amino acid headgroups, such as phosphatidylethanolamine and phosphatidylserine, were successfully released from the IPLS 
and derivatized. Using commercially available pure compounds it was established that $\delta^{15} \mathrm{~N}$ values of ethanolamine and glycine were not statistically different compared to offlinedetermined values. Application of the technique to microbial cultures and a microbial mat showed that the method works well for the release and derivatization of the headgroup of phosphatidylethanolamine, a common IPL in bacteria.

\section{CONCLUSIONS}

We developed a method to enable CSIA of nitrogen of selected IPLS. The method is suitable for measuring natural stable nitrogen isotopes in microbial lipids, in particular phosphatidylethanolamine, and will be especially useful to trace the fate of nitrogen in deliberate tracer experiments.

\section{Introduction}

Intact polar lipids (IPLS) in eukaryotes and bacteria generally comprise fatty acids esterified to glycerol, while in archaea they consist of isoprenoid alkyl chains which are ether bound to glycerol. These lipids often also contain polar headgroups which have a large structural diversity. The most commonly occurring are those with choline or ethanolamine headgroups, such as phosphatidylcholine and phosphatidylethanolamine, while other IPL headgroups can consist of e.g. sugars (glycolipids) or amino acids. Some of these IPLS are source specific and can be used to trace microbes in the natural environment. [e.g. 1,2,3]

Many methods have been developed to measure the isotopic composition of lipids as a means to obtain the natural stable isotopic signature of specific organisms, particularly of microbes, and for tracing the incorporation of labels in microbes in deliberate tracer experiments. ${ }^{\text {[e.g. 4] }}$ Since these compounds generally have to be amenable to gas chromatographic separation, lipid extracts are often analyzed as core lipids (e.g. fatty acids) following base hydrolysis of the ester bonds and derivatization, or, for archaeal lipids, by $\mathrm{HI} / \mathrm{LiAlH}_{4}$ cleavage of the ether bonds. ${ }^{\text {e.g. }}$ 5,6] Most of the compound specific stable isotope analysis (CSIA) of lipids has focused on determining the natural ${ }^{13} \mathrm{C}$-contents or the incorporation of ${ }^{13} \mathrm{C}$-labelled substrates into these core lipids, but has also been extended to include hydrogen isotopes, $\delta^{2} \mathrm{H}^{\left[{ }^{[7-10]}\right.}$ Some studies have also examined the stable carbon isotopic composition $\left(\delta^{13} \mathrm{C}\right)$ of headgroups and the glycerol backbone of IPLs. For example, Takano et al. ${ }^{[11]}$ analyzed the $\delta^{13} \mathrm{C}$ of the glycerol moiety of ether lipids using boron tribromide $\left(\mathrm{BBr}_{3}\right)$, and Lin et al. ${ }^{[12]}$ developed a method to analyze the ${ }^{13} \mathrm{C}$ contents of sugar headgroups after methanolysis of the IPLs and aldonitrile derivatization. However, to the best of our knowledge, no studies have been performed to determine the stable nitrogen isotopic composition of IPLs. Nitrogen-containing headgroups are widespread in membrane lipids among both bacteria (e.g. phosphatidylethanolamine; I in Figure 1) and eukaryotes (e.g. phosphatidylcholine, IV in Figure 1) and in intermediaries of lipid biosynthesis (e.g. phosphatidylserine and 
cytidine diphosphate diacylglycerol; V and VII in Figure 1, respectively). Recent studies of IPLs in cultures and the natural environment has shown that there is a large diversity in IPL structures and that a number of them are selective for certain groups of microorganisms. For example, ladderane lipids with a phosphatidylcholine headgroup are indicators for anammox bacteria ${ }^{[13]}$, while certain glycerol dibiphytanyl glycerol tetraether with a phosphohexose headgroup are good indicators for the archaeal groups, such as the Thaumarchaeota ${ }^{[14]}$ Stable nitrogen isotope analysis of headgroups of specific IPLs would thus provide a way to trace nitrogen isotopes in specific groups of bacteria and eukaryotes, which until now was only possible by analyzing the $\delta^{15} \mathrm{~N}$ of amino acids. ${ }^{[\text {e.g. } 15,16]}$ In contrast to IPLs, amino acids are rarely specific for groups of bacteria or eukaryotes. The exception is Damino acids, such as D-alanine, which occurs predominantly in bacteria and thus its isotopic composition can be used to trace the incorporation of e.g. ${ }^{15} \mathrm{~N}$-labelled substrates in bacterial communities in the natural environment. ${ }^{[15,17]}$

To analyze the nitrogen-containing headgroups of IPLs, we developed novel methodology for the direct determination of the $\delta^{15} \mathrm{~N}$ values of the nitrogen-containing lipid headgroups using GC/C/IRMS. The method is based on the compound-specific determination of $\delta^{15} \mathrm{~N}$ values of amino acids developed and refined by Metges et al. ${ }^{[18]}$ and Chikaraishi et al. ${ }^{[19,20]}$ The procedure was adapted for IPLs and tested on a number of
IPL standards and several bacterial cultures as well as a microbial mat.
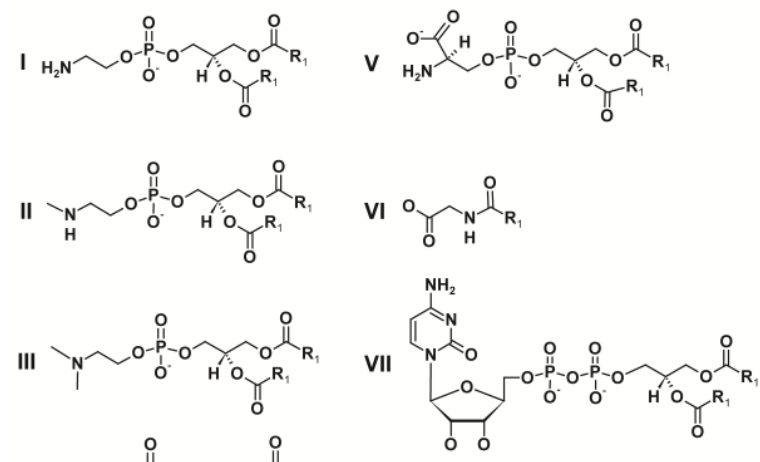

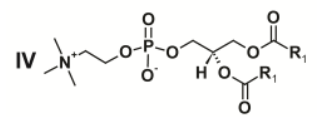

Figure 1. Structures of intact polar lipids tested in this study. I = phosphatidylethanolamine (PE), II = monomethyl-phosphatidylethanolamine (MMPE), III = dimethyl-phosphatidylethanolamine (DMPE), IV = phosphatidylcholine (PC); V = phosphatidylserine (PS); VI = N-acyl-glycine; VII = cytidine diphosphate (CDP).

\section{Experimental}

\section{Standards and culture material}

Intact polar lipid standards comprising a number of different $\mathrm{N}$-containing headgroups (Figure 1; Table 1) were purchased from Avanti Polar Lipids, Inc. (Alabaster, AL, USA).

The photoautotrophic purple sulfur bacterium Thiocapsa roseopersicina (strain DSM-217 ${ }^{[21]}$ ) was grown on a modified Pfenning's medium ${ }^{[22]}$ containing $0.34 \mathrm{~g}$ $\mathrm{NH}_{4} \mathrm{Cl}, 0.34 \mathrm{~g} \mathrm{KH}_{2} \mathrm{PO}_{4}, 0.5 \mathrm{~g} \mathrm{MgSO}_{4} .7 \mathrm{H}_{2} \mathrm{O}$, $0.34 \mathrm{~g} \mathrm{KCl} 0.25 \mathrm{~g} \mathrm{CaCl}_{2} .2 \mathrm{H}_{2} \mathrm{O}, 1.5 \mathrm{~g} \mathrm{NaHCO}_{3}$, $0.4 \mathrm{~g} \mathrm{Na}_{2} \mathrm{~S} .9 \mathrm{H}_{2} \mathrm{O}, 0.02 \mathrm{~g}$ vitamin $\mathrm{B} 12$, and 1 $\mathrm{mL}$ trace element solution SL-12 (Pfennig, 1965) per liter of distilled water at a $\mathrm{pH}$ of 77.5. The culture was incubated in airtight bottles at $25^{\circ} \mathrm{C}$ and a light intensity of approximately 1300 lux (16 h light, 8 h dark). 
Table 1. Stable nitrogen isotopic composition of headgroups released from intact polar lipid standards. $\mathrm{PE}=$ phosphatidylethanolamine; $P C=$ phosphatidylcholine; $P S=$ phosphatidylserine; $C D P=c y t i d i n e$ diphosphate; DAG=diacylglycerol. See Figure 1 for chemical structures.

\begin{tabular}{lllcccccc} 
& Acid & Hydrolysis & \multicolumn{2}{c}{$\delta^{15} \mathbf{N}_{\text {(CSIA) }}$} & \multicolumn{2}{c}{$\delta^{15} \mathbf{N}_{\text {(BULK) }}$} & \multicolumn{2}{c}{$\Delta \delta^{15} \mathbf{N}_{\text {(CSIA-BULK) }}$} \\
Polar lipid & Hydrolyzed & product & Avg & SD & Avg & SD & Avg & SD \\
\hline PE-DAG & yes & Ethanolamine & 0.7 & 0.6 & -0.7 & 0.6 & 1.4 & 0.9 \\
monomethyl-PE-DAG & yes & $\begin{array}{l}\text { CH3- } \\
\text { ethanolamine }\end{array}$ & 13.5 & 0.3 & - & - & - & - \\
dimethyl-PE-DAG & yes & No product & - & - & - & - & - & - \\
PC-DAG & yes & No product & - & - & - & - & - & - \\
CDP-DAG & yes & Cytidine* & -2.2 & 0.7 & 5.5 & 0.5 & $-7.6^{* *}$ & 0.9 \\
Amino acid & & & & & & & & \\
PS-DAG & yes & Serine & -2.3 & 0.2 & 3.0 & 0.9 & $-5.3^{* *}$ & 1.0 \\
N-palmitoylglycine & no & Glycine & -0.8 & - & 0.9 & 0.1 & -1.6 & - \\
\hline
\end{tabular}

*= contains multiple nitrogen

$* *=$ statistically significant different (Student's t-test, $\mathrm{p}<0.05$ )

The chemolithoautotrophic sulfide oxidizer Thiobacillus denitrificans (strain DSM$12475^{[21]}$ ) was grown on a medium containing $2 \mathrm{~g} \mathrm{KH}_{2} \mathrm{PO}_{4}, 2 \mathrm{~g} \mathrm{KNO}_{3}, 1 \mathrm{~g} \mathrm{NH}{ }_{4} \mathrm{Cl}$, $0.8 \mathrm{~g} \mathrm{MgSO}_{4} .7 \mathrm{H}_{2} \mathrm{O}$, and $2 \mathrm{~mL}$ trace element solution SL-4, $5 \mathrm{~g} \mathrm{Na}_{2} \mathrm{~S}_{2} \mathrm{O}_{3} .7 \mathrm{H}_{2} \mathrm{O}, 1 \mathrm{~g} \mathrm{NaHCO}_{3}$, $2 \mathrm{mg} \mathrm{FeSO} 4.7 \mathrm{H}_{2} \mathrm{O}$, and $1 \mathrm{~mL} 0.1 \mathrm{~N} \mathrm{H}_{2} \mathrm{SO}_{4}$ per liter of distilled water at a $\mathrm{pH}$ of 7.0. The trace element solution SL-4 contained 0.5 g EDTA, $0.2 \mathrm{~g} \mathrm{FeSO}_{4} .7 \mathrm{H}_{2} \mathrm{O}, 0.01 \mathrm{~g} \mathrm{ZnSO}_{4} .7 \mathrm{H}_{2} \mathrm{O}, 3 \mathrm{mg}$ $\mathrm{MnCl}_{2} .4 \mathrm{H}_{2} \mathrm{O}, 0.03 \mathrm{~g} \mathrm{H}_{3} \mathrm{BO}_{3}, 0.02 \mathrm{~g} \mathrm{CoCl}_{2} .6$ $\mathrm{H}_{2} \mathrm{O}, 1 \mathrm{mg} \mathrm{CuCl} 2.2 \mathrm{H}_{2} \mathrm{O}, 2 \mathrm{mg} \mathrm{NiCl} 2.6 \mathrm{H}_{2} \mathrm{O}$, and $3 \mathrm{mg} \mathrm{Na} 2 \mathrm{MoO}_{4} .2 \mathrm{H}_{2} \mathrm{O}$ per liter of distilled water. $T$. denitrificans cultures were incubated at $25^{\circ} \mathrm{C}$. Samples were collected in the stationary phase by centrifugation of culture samples in Falcon tubes.Pseudomonas sp., a gram-negative, aerobic gammaproteobacterium, was grown on an ammonium-glucose medium as described in Heinzelmann et al. ${ }^{[23]}$ The ammonium-glucose medium contained $5 \mathrm{~g}$ glucose, $0.2 \mathrm{~g} \mathrm{MgSO}_{4} .7 \mathrm{H}_{2} \mathrm{O}, 5 \mathrm{~g} \mathrm{NaCl}, 1.3 \mathrm{~g}$ $\left(\mathrm{NH}_{4}\right)_{2} \mathrm{HPO}_{4}, 1 \mathrm{~g} \mathrm{KH}_{2} \mathrm{PO}_{4}, 2 \mathrm{~mL}$ trace element solution SL-4 per liter of distilled water $(\mathrm{pH}$ 7.1). The culture was incubated at $25^{\circ} \mathrm{C}$.
Escherichia coli (strain TOP10) culture was grown on Minimal M9 media, amended with glucose and casamino acids containing $17 \mathrm{~g}$ $\mathrm{Na}_{2} \mathrm{HPO}_{4} .12 \mathrm{H}_{2} \mathrm{O}, 3.0 \mathrm{~g} \mathrm{KH}_{2} \mathrm{PO}_{4}, 0.5 \mathrm{~g} \mathrm{NaCl}, 1.0$ g NH $\mathrm{N}_{4} \mathrm{Cl}$ per liter of distilled water, $4.0 \mathrm{mM}$ $\mathrm{MgSO}_{4}, 0.2 \mathrm{mM} \mathrm{CaCl}$ and $0.4 \%$ of glucose and casamino acid solutions.

Pseudoalteromonas haloplanktis (strain DSM $6060^{[21]}$ ) was grown at $28^{\circ} \mathrm{C}$ for $48 \mathrm{~h}$ in a modified $3 \mathrm{M}+$ medium $^{[24]}$ with $0.5 \%$ sodium acetate. The $3 \mathrm{M}+$ media contained $17.6 \mathrm{~g}$ $\mathrm{NaCl}, 1.47 \mathrm{~g} \mathrm{Na}_{2} \mathrm{SO}_{4}, 0.08 \mathrm{~g} \mathrm{NaHCO}_{3}, 0.25 \mathrm{~g}$ $\mathrm{KCl}, 0.04 \mathrm{~g} \mathrm{KBr}, 1.87 \mathrm{~g} \mathrm{MgCl}_{2} .6 \mathrm{H}_{2} \mathrm{O}, 0.41 \mathrm{~g}$ $\mathrm{CaCl}_{2} .2 \mathrm{H}_{2} \mathrm{O}, 0.008 \mathrm{~g} \mathrm{SrCl}_{2} .6 \mathrm{H}_{2} \mathrm{O}, 0.008 \mathrm{~g}$ $\mathrm{H}_{3} \mathrm{BO}_{3}, 0.005 \mathrm{~g} \mathrm{Na}_{2} \mathrm{SiO}_{3} .5 \mathrm{H}_{2} \mathrm{O}, 4.89 \mathrm{mg}$ $\mathrm{FeCl}_{3} . \mathrm{H}_{2} \mathrm{O}, 0.51 \mathrm{~g} \mathrm{NaCl}, 0.23 \mathrm{~g} \mathrm{~K}_{2} \mathrm{HPO}_{4}$, and $8.3 \mathrm{~g}$ 3-(N-morpholino)propanesulfonic acid buffer (MOPS).

The microbial mat sample was collected from a cyanobacteria dominated mat on the Dutch island of Schiermonnikoog in November 2009. ${ }^{[25,26]}$ 
Extraction of intact polar lipids from cultures and microbial mat

Glassware was heated at $500^{\circ} \mathrm{C}$ for $4 \mathrm{~h}$ before use to remove organic material. All other labware was cleaned thoroughly, rinsed with bidistilled water, and dried at $100-130^{\circ} \mathrm{C}$ before use.

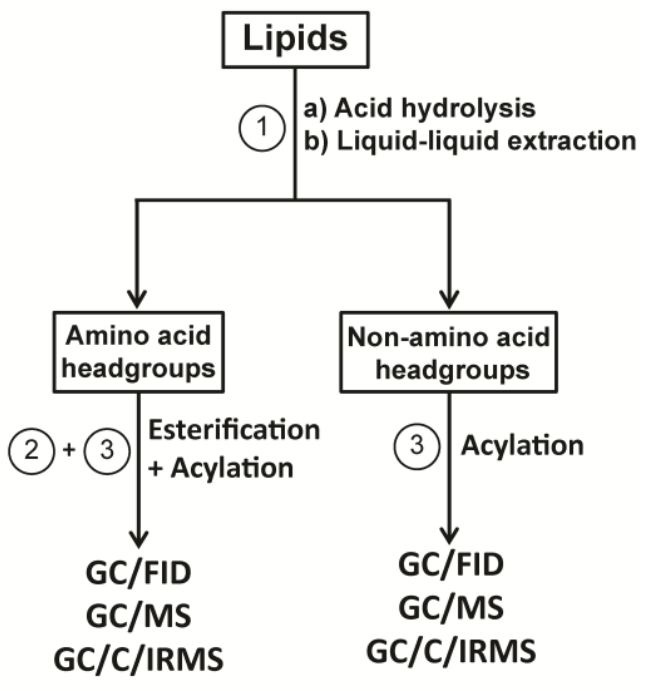

Figure 2. Scheme for release and derivatization of nitrogen-containing headgroups from intact polar lipids.

Extractions were carried out using a modified Bligh and Dyer procedure. ${ }^{[27,28]}$ A known volume of single-phase solvent mixture of methanol (MeOH): dichloromethane (DCM):phosphate buffer (PBS; 50 mM, pH 78) $(2: 1: 0.8, \mathrm{v} / \mathrm{v} / \mathrm{v})$ was added to $2-3 \mathrm{mg}$ of freeze-dried culture in a glass centrifuge tube and placed in an ultrasonic bath for $10 \mathrm{~min}$. The extract and residue were separated by centrifugation at $2000 \times g$ for $3 \mathrm{~min}$ and the solvent mixture collected in a separate flask. This process was repeated three times. DCM and PBS were then added to the extract to give a new ratio of $\mathrm{MeOH}: \mathrm{DCM}: \mathrm{PBS}$ of 1:1:0.9 $(\mathrm{v} / \mathrm{v} / \mathrm{v})$, and to induce phase separation. The extract was centrifuged at $2000 \times g$ for $3 \mathrm{~min}$ after which the DCM phase was collected in a round-bottom flask. The residual $\mathrm{MeOH}$ :PBS phase was washed two additional times with DCM, and the DCM phase added to the round-bottom flask. The combined DCM phases were reduced under rotary vacuum, transferred to a vial using MeOH/DCM (1:1 v/v) after which the solvents removed by evaporation under a stream of $\mathrm{N}_{2}$. Lipid extracts were stored at $20^{\circ} \mathrm{C}$ until further processing. IPLs in the lipid extract were identified using HPLC/ESI-MS ${ }^{n}$ following the method of Sturt et al. ${ }^{[29]}$ with some minor modifications. ${ }^{[2,30]}$

\section{Hydrolysis}

IPL standards $(0.2 \mathrm{mg}$ ) and Bligh and Dyer lipid extracts from cultures and microbial mat (approximately $2 \mathrm{mg}$ ) were dissolved in $\mathrm{MeOH} / \mathrm{DCM}(1: 1, \mathrm{v} / \mathrm{v})$ and transferred to 1$\mathrm{mL}$ Micro Reaction Vessels (Supelco, Zwijndrecht, The Netherlands). To release the headgroups from the IPLs, approximately $200 \mu \mathrm{l}$ of hydrochloric acid $(\mathrm{HCl}, 6 \mathrm{M})$ was added to the reaction vials and the mixture was hydrolyzed at $110^{\circ} \mathrm{C}$ for $18-20 \mathrm{~h}$ using a dry bath (VWR, Amsterdam, The Netherlands) (step 1 in Figure 2). Air was purged from the reaction vial by leaving the valve of a Mininert ${ }^{\circledR}$ cap (Supelco, SigmaAldrich, Zwijndrecht, The Netherlands) open until $\mathrm{HCl}$ fumes were detected using $\mathrm{pH}$ indicator paper. The hydrolysate was filtered using a centrifugal filtration device (10 s, 9000 x g; GHP Nanosep, Pall Co, Amsterdam, The Netherlands) and the filtrate transferred to a clean reaction vial. Approximately $200 \mu \mathrm{l}$ $n$-hexane/DCM $(3: 2, v / v)$ was added to the filtrate, mixed thoroughly, and the upper organic layer pipetted off after phase separation (3x). The remaining acidic solution (containing the headgroups) was dried by 
addition of $\mathrm{MeOH}$ and evaporation under $\mathrm{N}_{2}$ (3x).

\section{Derivatization}

Nitrogen-containing headgroups were derivatized based on the method described by Metges et al. ${ }^{[18]}$ and Chikaraishi et al. ${ }^{[19,20]}$ for the compound-specific stable isotope analysis of amino acids. Amino acid headgroups released during acid hydrolysis (e.g. phosphatidylserine, V Figure 1) were first esterified (step 2 in Figure 1) followed by acetylation (step 3 in Figure 1). Esterification was performed in the $1-\mathrm{mL}$ reaction vials using 2-propanol acidified with acetyl chloride $(4: 1, v / v)$, at $110^{\circ} \mathrm{C}$ for $2 \mathrm{~h}$. Air was purged from the reaction vial by leaving the valve of the Mininert $^{\circledR}$ cap open for approximately $20 \mathrm{~s}$ after placing the vials in the hot dry bath. Samples were cooled down to room temperature and solvents were removed under a gentle stream of $\mathrm{N}_{2}$. Excess reagents were removed by repeated washes (2x) with approximately $200 \mu \mathrm{L}$ DCM, and evaporation under a gentle stream of $\mathrm{N}_{2}$.

Non-amino acid headgroups were acetylated directly (step 3 in Figure 2) without prior esterification. Acetylation was performed in the reaction vial at $110^{\circ} \mathrm{C}$ for $2 \mathrm{~h}$, using a mixture of pivaloyl chloride (99\%, SigmaAldrich) and DCM (1:4: v/v). Air was purged from the reaction vial by leaving the valve of the Mininert ${ }^{\circledR}$ cap open for $10-20$ s after placing the vials in the dry bath. Samples were cooled down and solvents were removed under a gentle stream of $\mathrm{N}_{2}$. To remove excess reagents, approximately 200 $\mu$ I DCM was added, after which the solvents were removed under a gentle stream of $\mathrm{N}_{2}$ (2x). Liquid-liquid extraction was done by addition of approximately $200 \mu$ bidistilled water and $500 \mu$ l of $n$-hexane/DCM (3:2 v/v) to the extracts. After shaking the sample for $10 \mathrm{~s}$, the aqueous and organic phases were allowed to separate completely, after which the top/organic layer, containing the derivatives, was pipetted off and onto a magnesium sulfate column $(1-1.5 \mathrm{~cm}$ of $\mathrm{MgSO}_{4}$ in a Pasteur pipette). This was repeated three times. Solvents were removed under a gentle stream of $\mathrm{N}_{2}$ until a few microliters remained. The filtrate was then diluted in dried $\left(1 \% \mathrm{MgSO}_{4}\right)$, sonicated, DCM and stored at $-20^{\circ} \mathrm{C}$ until analysis.

\section{Gas chromatography}

The derivatized compounds were analyzed using a HP5890 gas chromatograph with flame ionization detector (GC/FID, Agilent Technologies, Amstelveen, The Netherlands). Separation of derivatives was achieved on a DB-5ms column (Agilent J\&W Agilent Technologies, Amstelveen, The Netherlands), either a $50 \mathrm{~m} \times 0.25 \mathrm{~mm}$ i.d., $0.25 \mu \mathrm{m}$ film thickness or a $60 \mathrm{~m} \times 0.32 \mathrm{~mm}$ i.d., $0.50 \mu \mathrm{m}$ film thickness, using the temperature programs described in Supplemental Table 1. Carrier gas was helium

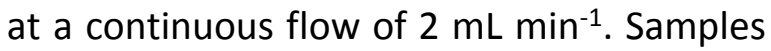
were injected using an on-column injector which tracked the oven temperature.

Identification of derivatives was done with $\mathrm{GC} /$ mass spectrometry (GC/MS) using an Agilent 7890A gas chromatograph interfaced with a $5975 \mathrm{C}$ or $5977 \mathrm{~A}$ mass selective detector (MSD). Columns and temperature programs are described in Supplemental Table 1. Carrier gas was helium at a continuous flow of $2 \mathrm{~mL} \mathrm{~min}^{-1}$. 
Continuous flow gas chromatography-isotope ratio mass spectrometry (GC/C/IRMS)

The $\delta^{15} \mathrm{~N}$ values of $\mathrm{N}, \mathrm{O}$-pivaloyl derivatives was determined by $\mathrm{GC} / \mathrm{C} / \mathrm{IRMS}$ using a Delta $\checkmark$ Advantage (Thermo Scientific, Breda, The Netherlands) connected to an Agilent 6890 gas chromatograph. The gas chromatograph and isotope ratio-mass spectrometer were interfaced via a combustion furnace $\left(980^{\circ} \mathrm{C}\right)$, reduction furnace $\left(650^{\circ} \mathrm{C}\right)$, and a liquid $\mathrm{N}_{2}$ cold trap. The oxidation oven contained one nickel, one platinum and one copper wire which were intertwined. The reduction oven contained four intertwined copper wires. Derivatives of headgroups were analyzed using a $60 \mathrm{~m}$ DB-5ms column as described for the $\mathrm{GC}$ and using an identical temperature program (Supplemental Table 1). Carrier gas was helium at a continuous flow of $2 \mathrm{~mL} \mathrm{~min}^{-}$ $1\left(29 \mathrm{~cm} \mathrm{sec}^{-1}\right)$. Injection volumes ranged from $0.4-2 \mu \mathrm{l}$ and were injected through cold column injection which tracked the oven temperature.

Stable isotope ratios are expressed using the $\delta$ notation in units per mil according to:

$$
\begin{aligned}
& \left.\delta \quad=\left(\left(R_{\text {sample }} / R_{\text {standard }}\right)-1\right), \quad \text { [Equation } 1\right] \\
& \text { where } R={ }^{15} \mathrm{~N} /{ }^{14} \mathrm{~N}
\end{aligned}
$$

and expressed in per mil versus air. The isotopes values are referenced against external $\mathrm{N}_{2}$ gas. An in-house standard mixture consisting of five derivatized amino acids (glycine, norleucine, glutamic acid, phenylalanine, and tyrosine) with known $\delta^{15} \mathrm{~N}$ values (determined offline) was used to evaluate daily system performance. Longterm reproducibility ( $>1$ year), based on the standard deviation of multiple injections $(n=52)$ of this standard was \pm 0.7 (glycine), \pm 0.9 (norleucine), and $\pm 1.2 \%$ (phenylalanine, glutamic acid, and tyrosine).

\section{Elemental analyzer - isotope ratio mass spectrometry (EA/IRMS)}

The bulk stable nitrogen isotopic ratios of lipid standards and bacterial biomass were determined using a Delta V Advantage isotope ratio-mass spectrometer coupled to a Flash 2000 elemental analyzer (Thermo Scientific, Breda, The Netherlands). Samples with a low ratio of nitrogen to carbon atoms were analyzed on a Delta XL isotope ratiomass spectrometer coupled to a Carlo Erba Instruments Flash 1112 Series (Thermo Scientific, Breda, The Netherlands) elemental analyzer and equipped with a solid $\mathrm{CO}_{2}$ trap, which removes $\mathrm{CO}_{2}$ from the sample stream and allows for the nitrogen isotope analysis of a larger amount of sample. An acetanilide standard with a $\delta^{15} \mathrm{~N}$ value of 1.18 (standard obtained from Arndt Schimmelmann, Indiana University, Bloomington, IN, USA $\left.{ }^{[31]}\right)$, and known \%TOC and \%TN content, was used for calibration. The acetanilide was calibrated against IAEA N-standards. The average repeatability of $\delta^{15} \mathrm{~N}$ determination was $0.2 \%$ based on repeated analysis of the acetanilide standard over time.

\section{Results \& Discussion}

\section{Release and analysis of IPL headgroups}

Our method for the determination of $\delta^{15} \mathrm{~N}$ values of IPLS headgroups is based on the method described by Metges et al. ${ }^{[18]}$ and Chikaraishi et al. ${ }^{[19,20]}$ for the compoundspecific stable isotope analysis of amino acids. The IPL standards and lipid extracts were first acid hydrolyzed (step 1 in Figure 2), to release the headgroups from the IPLs, 
followed by derivatization to make polar compounds GC-amenable. Amino acid containing IPLS require both esterification of the carboxyl group and acetylation of the amine group (step 2 and 3; Figure 2). For other headgroups, acetylation with pivaloyl chloride is sufficient (step 3, Figure 2). To test the method, seven IPL standards (Table 1; Figure 1) were treated following this procedure and the products were analyzed and identified by GC/FID and GC/MS. Of the seven standards, five yielded GC-amenable products identifiable by GC/MS (Table 1). As an example, the products released from phosphatidylethanolamine diacylglycerol (PE; I in Figure 1) are shown in Figure $3 \mathrm{~A}$ and reveal the presence of two main products. Based on mass spectral interpretation (Figure $3 C)$, the early eluting compound was identified as the pivaloyl derivative of ethanolamine ( $\mathrm{N}, \mathrm{O}$-pivaloyl ethanolamine), while the later eluting compound was identified as the pivaloyl derivative of glycerol (O-pivaloyl glycerol). Other IPLs for which the derivatized headgroups could be identified were N-monomethyl ethanolamine (from N-monomethylphosphoethanolamine diacylglycerol, MMPE; II in Figure 1), serine (from phosphatidylserine diacylglycerol, PS; $\mathbf{V}$ in Figure 1), glycine (from N-palmitoylglycine; VI in Figure 1), and cytidine (from cytidine diphospho- diacylglycerol, CDP-DAG; VII in Figure 1) (see Supplemental Figure 1A-D for mass spectra). For some IPLs, such as $\mathrm{N}$ dimethyl-phosphatidylethanolamine diacylglycerol (DMPE; III in Figure 1) and phosphatidylcholine diacylglycerol (PC; IV in Figure 1), we could not identify any products which could be linked to the headgroup of those IPLs. This is likely due to the fact that pivaloyl chloride readily reacts with primary and secondary amines but not with the tertiary and quaternary amines present in DMPE and PC, resulting in (partially) underivatized products which were too volatile or too polar to be detected by GC analysis. This suggests that our method is not applicable to these types of IPLs and that alternative approaches, such as isolation by preparative HPLC followed by EA/IRMS analysis, are required in order to analyze their $\delta^{15} \mathrm{~N}$ values.

\section{Isotopic analysis of headgroups}

For the IPLS which yielded derivatized headgroups we determined the $\delta^{15} \mathrm{~N}$ values using GC/C/IRMS and compared them with offline values determined by EA/IRMS. Headgroups were in all but one case depleted in ${ }^{15} \mathrm{~N}$ compared with the offline values (1.6 to $7.6 \%$ ), suggesting isotopic fractionation during hydrolysis and derivatization (Table 1). The difference in $\delta^{15} \mathrm{~N}$ values between online (CSIA) and offline (BULK) values was statistically significant $(p<0.05)$ for PS and CDP but not for PE and glycine. Isotopic fractionation of nitrogen in amino acids has previously been observed after hydrolysis. ${ }^{[32-34]}$ Bada et al. ${ }^{[32]}$ found that the free amino acids released by hydrolysis from bone collagen were enriched in ${ }^{15} \mathrm{~N}$ compared to intact collagen although the difference was relatively small (1-2\%o). Silfer et al. ${ }^{[33]}$ looked at the isotopic fractionation of the glycine-glycine peptide bond and found that isotopic fractionation increased with both higher hydrolysis 

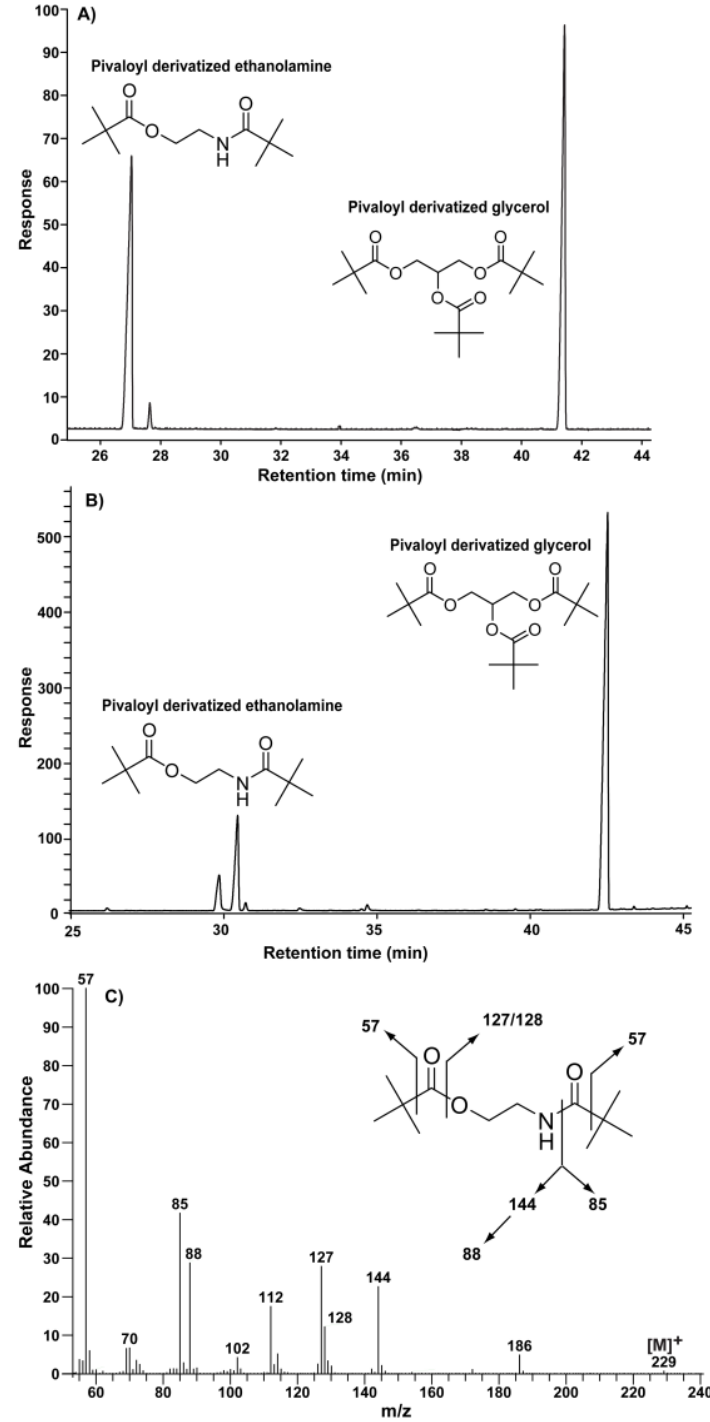

Figure 3. Gas chromatogram of derivatized products released from acid hydrolysis of: A) phosphatidylethanolamine (PE; see Figure 1 for structure) analysed on a $50 \mathrm{~m}$ DB-5 column (Supplemental Table 1), and B) a microbial mat from Schiermonnikoog analysed on a $60 \mathrm{~m}$ DB-5 column (Supplemental Table 1). C) Mass spectrum of the derivatized ethanolamine headgroup

temperature and increasing yield of hydrolysis, but again, differences in $\delta^{15} \mathrm{~N}$ values between the free amino acid and bulk material were relatively small $(<3 \%$ ). Our results for ethanolamine and glycine agree well with these studies, with $\Delta \delta^{15} N_{\text {(CSIA-BULK) }}$ values of IPLs generally $<2 \%$ but large fractionations are observed for CDP and serine. Hofmann et al. ${ }^{[34]}$ also found variable differences in isotopic fractionation induced by hydrolysis and derivatization for a variety of amino acids.

Together our results suggests that it possible to determine the $\delta^{15} \mathrm{~N}$ values of IPLs, but a correction may be needed for the isotopic fractionation induced by hydrolysis as well as derivatization. However, this issue is of lesser importance when the method is applied to trace ${ }^{15} \mathrm{~N}$ label incorporation into IPL headgroups.

\section{Application to cultures and a microbial mat}

As the $\delta^{15} \mathrm{~N}$ value of the derivatized ethanolamine headgroup from PE was not significantly different from that of the offline determined value, it appears that it would be feasible to analyze the natural stable isotopic composition of this particular headgroup. Since PE is a common nitrogen-containing headgroup in bacterial lipids, and is rare and in low abundance in eukaryotes and archaea, it can potentially be applied to study the $\delta^{15} \mathrm{~N}$ values of bacterial biomass in the natural environment.

We first tested our method on IPLs extracted from five bacterial cultures, one photoautotrophic bacterium (Thiocapsa roseopersicina), one obligate chemoautotrophic bacterium (Thiobacillus denitrificans) and three heterotrophic bacteria (Pseudomonas sp., 
Table 2. Microbial cultures and microbial mat $\delta^{15} \mathrm{~N}$ values of bulk biomass, phosphatidylethanolamine (PE) and serine (SER).

\begin{tabular}{|c|c|c|c|c|c|c|c|c|c|c|}
\hline & \multicolumn{2}{|c|}{ BULK } & \multicolumn{2}{|c|}{ PE } & \multicolumn{2}{|c|}{ Serine } & \multicolumn{2}{|c|}{$\begin{array}{c}\Delta \delta^{15} N_{(P E-} \\
\text { BULK) }\end{array}$} & \multicolumn{2}{|c|}{$\Delta \delta^{15} N_{\text {(PE-SER) }}$} \\
\hline & Avg & SD & Avg & SD & Avg & SD & Avg & SD & Avg & SD \\
\hline Thiocapsa roseopersicina & -5.3 & 0.7 & -9.5 & 0.6 & $\begin{array}{c}- \\
11.8\end{array}$ & & -4.2 & 0.8 & 2.3 & \\
\hline Thiobacillus denitrificans & -8.7 & 0.1 & $\begin{array}{c}- \\
17.0\end{array}$ & 1.0 & $\begin{array}{c}- \\
15.6\end{array}$ & 1.0 & -8.1 & 1.0 & -1.1 & 1.4 \\
\hline Escheria coli & 1.5 & 0.1 & -1.7 & 0.5 & -0.3 & & -3.2 & 0.5 & -1.5 & \\
\hline Pseudomonas sp. & $\begin{array}{c}- \\
11.7\end{array}$ & 0.1 & $\begin{array}{c}- \\
15.0\end{array}$ & 0.4 & $\begin{array}{c}- \\
13.4\end{array}$ & 0.6 & -3.3 & 0.5 & $\overline{-}^{-}$ & 0.7 \\
\hline $\begin{array}{l}\text { Pseudoalteromonas } \\
\text { haloplanktis }\end{array}$ & -3.0 & 0.1 & -3.2 & 0.5 & -4.8 & 0.8 & -0.2 & 0.5 & $1.6^{* *}$ & 1.0 \\
\hline Microbial mat & 1.6 & 0.5 & -0.3 & 0.9 & -2.8 & 0.2 & -1.8 & 1.0 & $2.5^{*}$ & 0.9 \\
\hline
\end{tabular}

Pseudoalteromonas haloplanktis, and Escherichia coli; Table 2), which have been reported to contain $\mathrm{PE}$ in their cell membranes. ${ }^{[35-39]}$ The presence of PE in all of these cultures was confirmed by HPLC/MS analysis of IPLs, and the derivatized headgroup of PE, $\mathrm{N}, \mathrm{O}$-pivaloyl ethanolamine, was detected by GC/MS in all cultures after application of our method. The $\delta^{15} \mathrm{~N}$ values of $\mathrm{N}, \mathrm{O}$-pivaloyl ethanolamine varied from -17.0 to $-0.3 \%$ and the compound was depleted in ${ }^{15} \mathrm{~N}$ compared to bulk biomass by 0.2 to 8.1 $\%$ (Table 2; Figure 4). These results compare well with a recent study of ours ${ }^{[40]}$ in which the nitrogen isotopic composition of total lipid extracts of several aquatic animals were found to be highly depleted in ${ }^{15} \mathrm{~N}$ compared to bulk biomass. The ${ }^{15} \mathrm{~N}$-depleted amino acid serine was thought to be the cause for this depletion as serine is one of the main sources of nitrogen to PC, which is one of the most abundant IPLs in these animals. ${ }^{[41]}$ As the nitrogen in $\mathrm{PE}$ is also derived from the amino acid serine, ${ }^{[42]}$ we determined the $\delta^{15} \mathrm{~N}$ value of serine released from proteins in the residual, lipid-free, biomass of the bacterial cultures. ${ }^{[18,19]}$ We found that serine in these bacteria was also depleted in ${ }^{15} \mathrm{~N}$ compared to bulk biomass, ranging from -15.6 to $-0.3 \%$ o

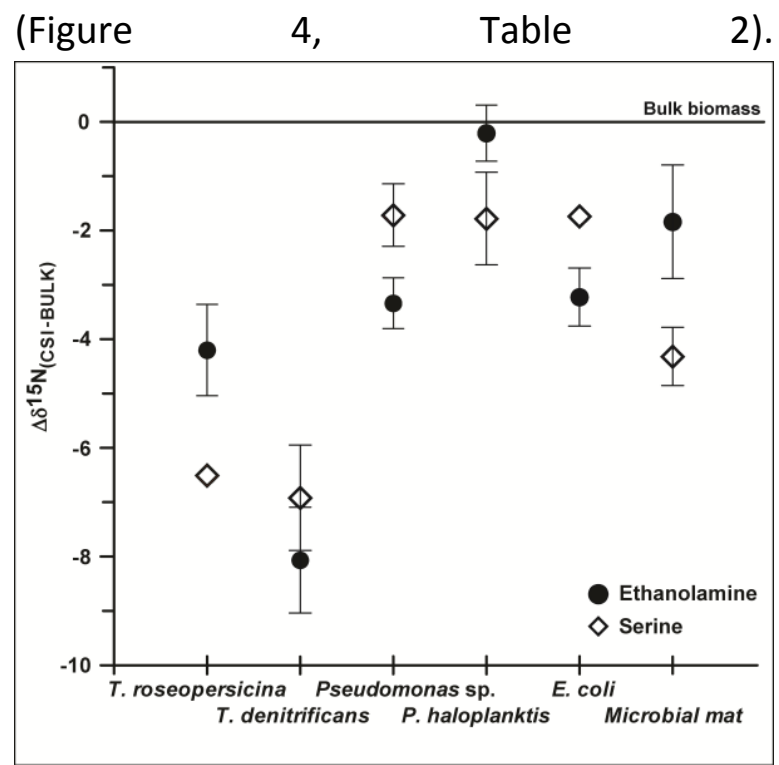

Figure 4. $\delta^{15} \mathrm{~N}$ values normalized to bulk $\delta^{15} \mathrm{~N}$ values for phosphatidylethanolamine headgroups (ethanolamine) and serine from five bacterial cultures. CSIA = compound specific isotope analysis.

Importantly, the $\delta^{15} \mathrm{~N}$ value of ethanolamine correlated well with that of serine released 
from proteins (Figure 5), suggesting that the $\delta{ }^{15} \mathrm{~N}$ values of bacterial PE lipids reflects that of the amino acid serine.

Interestingly, both serine and PE of the autotrophic bacteria ( $T$. roseopersicina and $T$. denitrificans) had similar quite negative $\Delta \delta^{15} \mathrm{~N}_{\text {(CSIA-BULK) }}$ values relative to that of the heterotrophic bacteria (E. coli, Pseudomonas sp., and P. haloplanktis; Figure 4). This difference in $\Delta \delta^{15} \mathrm{~N}$ between autotrophs and heterotrophs is likely caused by the fact that serine was synthesized by the autotrophic bacteria themselves while the heterotrophic bacteria obtained serine from the growth media. The method was also applied to a cyanobacteria dominated microbial mat from Schiermonnikoog island in the Dutch Wadden Sea, ${ }^{[26]}$ known to contain PE. ${ }^{[25]}$ The pivaloyl-derivative of ethanolamine was detected in the lipid extract from the mat after application of our procedure (Figure 3B). Isotopic analysis of this product (Supplemental Figure 2), as well as of serine derived from proteins, showed that, similar to our heterotrophic bacterial cultures, both ethanolamine and serine were depleted in ${ }^{15} \mathrm{~N}$ by 2 and $4 \%$, respectively, compared to bulk biomass. Interestingly, the depletion in ${ }^{15} \mathrm{~N}$ of PE compared to bulk biomass was in between that of the autotrophic and heterotrophic bacteria, suggesting that PE in the microbial mat was sourced both from autotrophic and heterotrophic sources. These results suggest that it is feasible to measure the $\delta^{15} \mathrm{~N}$ values of PE headgroups in natural samples using the method developed here. Since PE lipids in the environment are predominantly derived from bacteria, and not from eukaryotes or archaea, and the nitrogen isotopic composition of PE reflects that of serine, it provides a selective method capable of e.g. tracing the incorporation of ${ }^{15} \mathrm{~N}$-labelled substrates into bacterial biomass under in situ conditions. Other methods used to analyze the nitrogen isotope dynamics in microbial communities are rarely selective for certain microbial groups, e.g. most amino acids occur in all domains of life. The exception is D-alanine which is an amino acid predominantly occurring in bacteria and the ${ }^{15} \mathrm{~N}$ incorporation of $\mathrm{D}$-alanine has been used to trace the uptake of nitrogen substrates in bacteria ${ }^{[15]}$. However, D-alanine also occurs in some animals ${ }^{[43]}$ and measurement of $\delta^{15} \mathrm{~N}$ values of PE headgroups thus provides an independent method to trace nitrogen through the microbial domain in the natural environment

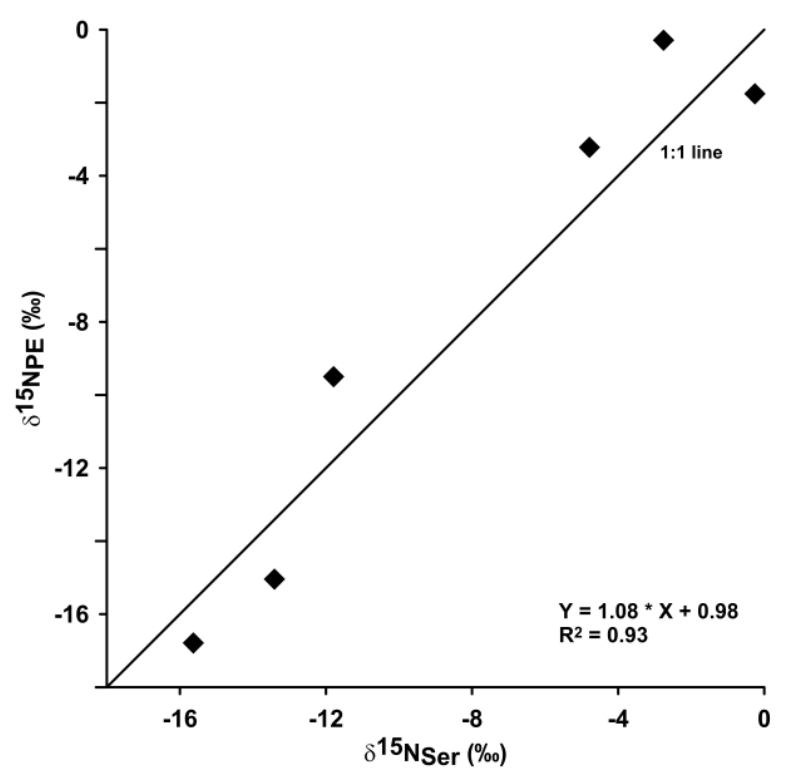

Figure $5 . \delta^{15} \mathrm{~N}$ values of serine (SER) versus $\delta^{15} \mathrm{~N}$ values of the phosphatidylethanolamine headgroup (PE). 


\section{Conclusions}

We developed a procedure for the measurement of $\delta^{15} \mathrm{~N}$ values of nitrogencontaining headgroups from intact polar lipids (IPLS). Our results show that the method works well for a select number of IPLs. Isotopic fractionations resulting from sample preparation were sometimes observed, suggesting some correction may be needed for some IPLs. No statistically significant fractionation was observed for the $\delta^{15} \mathrm{~N}$ value of phosphatidylethanolamine, an important bacterial headgroup. Application of this method on five bacterial cultures and a microbial mat showed a similar depletion in ${ }^{15} \mathrm{~N}$ of both $\mathrm{PE}$ and the amino acid serine compared to bulk biomass, indicating that the $\delta^{15} \mathrm{~N}$ signal of $\mathrm{PE}$ is reflecting the $\delta^{15} \mathrm{~N}$ value of its biosynthetic nitrogen source, serine. Autotrophic bacteria PE and serine were in general more depleted in ${ }^{15} \mathrm{~N}$ compared to the heterotrophic bacteria, probably because autotrophic bacteria synthesize serine while heterotrophs obtain serine from their food source. Regardless, since PE lipids in the natural environment are predominantly sourced by bacteria, the analysis of the $\delta^{15} \mathrm{~N}$ value of phosphatidylethanolamine headgroups provides the opportunity to investigate the nitrogen isotope dynamics in bacterial biomass under in situ conditions.

\section{Acknowledgements}

We thank three anonymous reviewers and the associate editor for their valuable comments which improved the manuscript. This work is part of the Waddensleutels project (http://www.waddensleutels.nl/) and supported by the Waddenfonds. The authors would like to thank Laura Villanueva and Sandra Heinzelmann for supplying bacterial cultures, and Lukas J. Stal, Haoxin Fan and Nicole Bale for providing the microbial mat sample, collected as part of the NICYCLE project supported by the Netherlands Organization for Scientific Research (NWO) through the grants 839.08.331 and 839.08.332. Ellen Hopmans, Anchelique Mets, and Monique Verweij are acknowledged for their invaluable assistance with analyses.

\section{References}

[1] A. Jaeschke, E. C. Hopmans, S. G. Wakeham, S. Schouten, J. S. Sinninghe Damsté. The presence of ladderane lipids in the oxygen minimum zone of the Arabian Sea indicates nitrogen loss through anammox. Limnol. Oceanogr. 2007, 52, 780.

[2] A. Pitcher, N. Rychlik, E. C. Hopmans, E. Spieck, W. I. C. Rijpstra, J. Ossebaar, S. Schouten, M. Wagner, J. S. Sinninghe Damsté. Crenarchaeol dominates the membrane lipids of Candidatus Nitrososphaera gargensis, a thermophilic Group I.1b Archaeon. ISME J. 2010, 4, 542.

[3] R. A. Gibson, M. T. J. van der Meer, E. C. Hopmans, A.-L. Reysenbach, S. Schouten, J. S. Sinninghe Damsté. Comparison of intact polar lipid with microbial community composition of vent deposits of the Rainbow and Lucky Strike hydrothermal fields. Geobiology 2013, 11, 72.

[4] H. T. S. Boschker, J. J. Middelburg. Stable isotopes and biomarkers in microbial ecology. FEMS Microbiol. Ecol. 2002, 40, 85.

[5] J. Hoefs. Stable Isotope Geochemistry. Springer Berlin Heidelberg, Berlin, Heidelberg, 1997. 
[6] S. Schouten, W. C. M. Klein Breteler, P. Blokker, N. Schogt, W. I. C. Rijpstra, K. Grice, M. Baas, J. S. Sinninghe Damsté. Biosynthetic effects on the stable carbon isotopic compositions of algal lipids: implications for deciphering the carbon isotopic biomarker record. Geochim. Cosmochim. Acta 1998, 62, 1397.

[7] R. H. Smittenberg, C. Saenger, M. N. Dawson, J. P. Sachs. Compound-specific $\mathrm{D} / \mathrm{H}$ ratios of the marine lakes of Palau as proxies for West Pacific Warm Pool hydrologic variability. Quat. Sci. Rev. 2011, 30, 921.

[8] X. Zhang, A. L. Gillespie, A. L. Sessions. Large $\mathrm{D} / \mathrm{H}$ variations in bacterial lipids reflect central metabolic pathways. Proc. Natl. Acad. Sci. 2009, 106, 12580.

[9] A. A. Jones, A. L. Sessions, B. J. Campbell, C. $\mathrm{Li}, \mathrm{D}$. L. Valentine. $\mathrm{D} / \mathrm{H}$ ratios of fatty acids from marine particulate organic matter in the California Borderland Basins. Org. Geochem. 2008, 39, 485.

[10] A. L. Sessions, L. L. Jahnke, A. Schimmelmann, J. M. Hayes. Hydrogen isotope fractionation in lipids of the methane-oxidizing bacterium Methylococcus capsulatus. Geochim. Cosmochim. Acta 2002, 66, 3955.

[11] Y. Takano, Y. Chikaraishi, N. O. Ogawa, H. Nomaki, Y. Morono, F. Inagaki, H. Kitazato, K.-U. Hinrichs, N. Ohkouchi. Sedimentary membrane lipids recycled by deep-sea benthic archaea. Nat. Geosci. 2010, 3, 858.

[12] Y.-S. Lin, J. S. Lipp, M. Y. Yoshinaga, S.-H. Lin, M. Elvert, K.-U. Hinrichs. Intramolecular stable carbon isotopic analysis of archaeal glycosyl tetraether lipids. Rapid Commun. Mass Spectrom. 2010, 24, 2817.

[13] A. Jaeschke, C. Rooks, M. Trimmer, J. C. Nicholls, E. C. Hopmans, S. Schouten, J. S. Sinninghe Damsté. Comparison of ladderane phospholipid and core lipids as indicators for anaerobic ammonium oxidation (anammox) in marine sediments. Geochim. Cosmochim. Acta 2009, 73, 2077.

[14] A. Pitcher, L. Villanueva, E. C. Hopmans, S. Schouten, G.-J. Reichart, J. S. Sinninghe Damsté. Niche segregation of ammoniaoxidizing archaea and anammox bacteria in the Arabian Sea oxygen minimum zone. ISME J. 2011, 5, 1896.

[15] B. Veuger, J. J. Middelburg, H. T. S. Boschker, M. Houtekamer. Analysis of $15 \mathrm{~N}$ incorporation into $D$-alanine: a new method for tracing nitrogen uptake by bacteria. Limnol. Oceanogr. Methods 2005, 3,230 .

[16] M. L. Calleja, F. Batista, M. Peacock, R. Kudela, M. D. McCarthy. Changes in compound specific $\delta^{15} \mathrm{~N}$ amino acid signatures and $\mathrm{D} / \mathrm{L}$ ratios in marine dissolved organic matter induced by heterotrophic bacterial reworking. Mar. Chem. 2013, 149, 32.

[17] B. Veuger, J. J. Middelburg, H. T. S. Boschker, M. Houtekamer. Update of "Analysis of $15 \mathrm{~N}$ incorporation into Dalanine: A new method for tracing nitrogen uptake by bacteria" (Veuger et al. 2005, Limnol. Oceanogr. Methods 3:230-240). Limnol. Oceanogr. Methods 2007, 5, 192.

[18] C. C. Metges, K. Petzke, U. Hennig. Gas chromatography/combustion/isotope ratio mass spectrometric comparison of $\mathrm{N}$ acetyl- and N-pivaloyl amino acid esters to measure ${ }^{15} \mathrm{~N}$ isotopic abundances in physiological samples: a pilot study on amino acid synthesis in the upper gastrointestinal tract of minipigs. J. Mass Spectrom. 1996, 31, 367.

[19] Y. Chikaraishi, Y. Kashiyama, N. O. Ogawa, H. Kitazato, N. Ohkouchi. Metabolic control of nitrogen isotope composition of amino acids in macroalgae and gastropods: implications for aquatic food web studies. Mar. Ecol. Prog. Ser. 2007, 342, 85. 
[20] Y. Chikaraishi, N. O. Ogawa, Y. Kashiyama, Y. Takano, H. Suga, A. Tomitani, H. Miyashita, H. Kitazato, N. Ohkouchi. Determination of aquatic food-web structure based on compound-specific nitrogen isotopic composition of amino acids. Limnol. Oceanogr. Methods 2009, 7, 740.

[21] DSMZ: Catalogue Microorganisms. can be found under https://www.dsmz.de/catalogues/catalogu e-microorganisms.html, n.d.

[22] DSMZ: List of Media for Microorganisms. can be found under https://www.dsmz.de/catalogues/catalogu e-microorganisms/culture-technology/listof-media-for-microorganisms.html, n.d.

[23] S. M. Heinzelmann, L. Villanueva, D. SinkeSchoen, J. S. Sinninghe Damsté, S. Schouten, M. T. J. van der Meer. Impact of metabolism and growth phase on the hydrogen isotopic composition of microbial fatty acids. Aquat. Microbiol. 2015, 6, 408.

[24] J. Östling, A. Goodman, S. Kjelleberg. Behaviour of IncP-1 plasmids and a miniMu transposon in a marine Vibrio sp.: isolation of starvation inducible lac operon fusions. FEMS Microbiol. Ecol. 1991, 9, 83.

[25] T. Bauersachs, J. Compaoré, I. Severin, E. C. Hopmans, S. Schouten, L. J. Stal, J. S. Sinninghe Damsté. Diazotrophic microbial community of coastal microbial mats of the southern North Sea: Coastal microbial mats of the North Sea. Geobiology 2011, 9, 349.

[26] H. Bolhuis, L. J. Stal. Analysis of bacterial and archaeal diversity in coastal microbial mats using massive parallel $16 \mathrm{~S}$ rRNA gene tag sequencing. ISME J. 2011, 5, 1701.

[27] E. G. Bligh, W. J. Dyer. A rapid method of total lipid extraction and purification. Can. J. Biochem. Physiol. 1959, 37, 911.

[28] A. Pitcher, C. Wuchter, K. Siedenberg, S. Schouten, J. S. Sinninghe Damsté. Crenarchaeol tracks winter blooms of ammonia-oxidizing Thaumarchaeota in the coastal North Sea. Limnol. Oceanogr. 2011, 56, 2308

[29] H. F. Sturt, R. E. Summons, K. Smith, M. Elvert, K.-U. Hinrichs. Intact polar membrane lipids in prokaryotes and sediments deciphered by highperformance liquid chromatography/electrospray ionization multistage mass spectrometry-new biomarkers for biogeochemistry and microbial ecology. Rapid Commun. Mass Spectrom. 2004, 18, 617.

[30] S. Schouten, E. C. Hopmans, M. Baas, H. Boumann, S. Standfest, M. Konneke, D. A. Stahl, J. S. Sinninghe Damsté. Intact membrane lipids of "Candidatus Nitrosopumilus maritimus", a cultivated representative of the cosmopolitan mesophilic Group I Crenarchaeota. Appl. Environ. Microbiol. 2008, 74, 2433.

[31] A. Schimmelmann, A. Albertino, P. E. Sauer, H. Qi, R. Molinie, F. Mesnard. Nicotine, acetanilide and urea multi-level ${ }^{2} \mathrm{H}-,{ }^{13} \mathrm{C}$ and ${ }^{15} \mathrm{~N}$-abundance reference materials for continuous-flow isotope ratio mass spectrometry. Rapid Commun. Mass Spectrom. 2009, 23, 3513.

[32] J. L. Bada, M. J. Schoeninger, A. Schimmelmann. Isotopic fractionation during peptide bond hydrolysis. Geochim. Cosmochim. Acta 1989, 53, 3337.

[33] J. A. Silfer, M. H. Engel, S. A. Macko. Kinetic fractionation of stable carbon and nitrogen isotopes during peptide bond hydrolysis: Experimental evidence and geochemical implications. Chem. Geol. Isot. Geosci. Sect. 1992, 101, 211. 
[34] D. Hofmann, M. Gehre, K. Jung. Sample preparation techniques for the determination of natural $15 N / 14 N$ variations in amino acids by gas chromatography-combustion-isotope ratio mass spectrometry (GC-C-IRMS). Isotopes Environ. Health Stud. 2003, 39, 233.

[35] G. F. Ames. Lipids of Salmonella typhimurium and Escherichia coli: Structure and Metabolism. J. Bacteriol. 1968, 95, 833.

[36] J. K. Barridge, J. M. Shively. Phospholipids of the thiobacilli. J. Bacteriol. 1968, 95, 2182.

[37] S. G. Wilkinson, L. Galbraith, G. A. Lightfoot. Cell walls, lipids, and Ipopolysaccharides of Pseudomonas species. Eur. J. Biochem. 1973, 33, 158.

[38] J. F. Imhoff, D. J. Kushner, S. C. Kushwaha, M. Kates. Polar lipids in phototrophic bacteria of the Rhodospirillaceae and Chromatiaceae families. J. Bacteriol. 1982, 150, 1192.
[39] G. M. Frolova, V. V. Kurilenko, E. P. Ivanova, N. M. Gorshkova, V. V. Mikhailov. Phospholipids of marine proteobacteria of the genus Pseudoalteromonas. Microbiology 2000, 69, 417.

[40] E. Svensson, S. Schouten, E. C. Hopmans, J. J. Middelburg, J. S. S. Sinninghe Damsté. Stable nitrogen isotope composition $\left(\delta^{15} \mathrm{~N}\right)$ of lipids in marine animals reflect the stable nitrogen isotope composition of the base of the food web. in revision for PLOS ONE.

[41] L. K. Cole, J. E. Vance, D. E. Vance. Phosphatidylcholine biosynthesis and lipoprotein metabolism. Biochim. Biophys. Acta BBA - Mol. Cell Biol. Lipids 2012, 1821, 754.

[42] C. Ratledge. Microbial Lipids. Academic Press, London, 1989.

[43] H. Abe, N. Yoshikawa, M. G. Sarower, S. Okada. Physiological function and metabolism of free $D$-alanine in aquatic animals. Biol. Pharm. Bull. 2005, 28, 1571. 
Table S1

\begin{tabular}{|c|c|c|c|c|c|c|c|c|}
\hline \multirow[b]{2}{*}{ Species } & \multirow[b]{2}{*}{ Tissue } & \multirow[b]{2}{*}{ \%lipid } & \multicolumn{2}{|c|}{ Bulk biomass } & \multicolumn{2}{|c|}{ Lipid-free biomass } & \multicolumn{2}{|c|}{ Total lipid extract } \\
\hline & & & d15N & C:N & d15N & C:N & d15N & C:N \\
\hline \multirow[t]{6}{*}{ Atlantic herring } & Gill & 30 & 11,5 & 5,6 & 11,8 & 3,3 & 6,3 & NA \\
\hline & & 32 & 10,6 & 8,0 & 10,7 & 3,2 & 5,2 & NA \\
\hline & & 25 & 10,6 & 6,0 & 10,7 & 3,2 & NA & NA \\
\hline & & 19 & 11,2 & 4,8 & 13,0 & 3,3 & NA & NA \\
\hline & & 30 & 11,1 & 6,0 & 12,0 & 3,0 & 9,2 & NA \\
\hline & & 21 & 14,4 & 6,6 & 13,7 & 3,1 & 0,4 & 62,9 \\
\hline \multirow[t]{6}{*}{ Atlantic herring } & Muscle & 8 & 13,7 & 3,4 & 14,2 & 3,1 & 2,7 & NA \\
\hline & & 34 & 11,7 & 6,1 & 12,5 & 3,1 & 2,9 & NA \\
\hline & & 8 & 11,4 & 3,3 & 12,2 & 3,0 & $-0,5$ & 23,2 \\
\hline & & 32 & 11,8 & 5,8 & 12,8 & 3,1 & NA & NA \\
\hline & & 40 & 11,5 & 5,8 & 13,2 & 3,1 & 2,4 & NA \\
\hline & & 7 & 16,2 & 3,3 & 16,3 & 3,0 & 3,1 & 14,6 \\
\hline \multirow[t]{6}{*}{ Brown trout } & Gill & 10 & 15,0 & 3,9 & 15,3 & 3,2 & 11,5 & NA \\
\hline & & 8 & 13,9 & 3,8 & 14,2 & 3,2 & 7,2 & 19,5 \\
\hline & & 9 & 16,3 & 3,8 & 16,3 & 3,3 & 11,0 & NA \\
\hline & & 6 & 16,0 & 4,0 & 16,6 & 3,5 & NA & NA \\
\hline & & 3 & 15,9 & 3,7 & 16,6 & 3,2 & NA & NA \\
\hline & & 7 & 16,1 & 3,8 & 16,7 & 3,2 & 8,5 & 42,2 \\
\hline \multirow[t]{6}{*}{ Brown trout } & Muscle & 25 & 15,3 & 5,1 & 15,5 & 3,1 & 5,8 & NA \\
\hline & & 5 & 13,7 & 3,2 & 14,4 & 3,0 & 4,3 & NA \\
\hline & & 9 & 16,1 & 3,3 & 16,6 & 3,2 & 7,7 & NA \\
\hline & & 6 & 15,9 & 3,2 & 16,8 & 3,1 & NA & NA \\
\hline & & 8 & 16,5 & 3,3 & 17,0 & 3,1 & 9,7 & 21,3 \\
\hline & & 15 & 16,4 & 4,0 & 16,8 & 3,0 & 7,0 & NA \\
\hline \multirow[t]{2}{*}{ Twait shad } & Gill & 9 & 16,7 & 4,2 & 17,0 & 3,3 & NA & NA \\
\hline & & 6 & 14,7 & 4,3 & 14,8 & 3,6 & NA & NA \\
\hline \multirow[t]{2}{*}{ Twait shad } & Muscle & 6 & 17,1 & 3,2 & 17,9 & 3,1 & 10,3 & 14,1 \\
\hline & & 6 & 15,8 & 3,2 & 16,7 & 3,1 & NA & NA \\
\hline \multirow[t]{3}{*}{ Green shore crab } & Muscle & 4 & 13,2 & 3,8 & 13,4 & 3,6 & 8,2 & NA \\
\hline & & 2 & 15,8 & 3,7 & 16,5 & 3,3 & NA & NA \\
\hline & & 6 & 13,9 & 5,3 & 14,3 & 4,4 & NA & NA \\
\hline \multirow[t]{5}{*}{ Common cockle } & Muscle & 5 & 11,3 & 4,6 & 12,0 & 4,1 & NA & NA \\
\hline & & 5 & 11,5 & 4,9 & 11,9 & 4,3 & 7,2 & NA \\
\hline & & 5 & 12,1 & 4,7 & 11,7 & 4,1 & 6,9 & NA \\
\hline & & 4 & 12,6 & 4,1 & 12,7 & 3,7 & NA & NA \\
\hline & & 3 & 12,0 & 4,5 & 11,9 & 4,1 & NA & NA \\
\hline \multirow[t]{2}{*}{ Pacific oyster } & Muscle & 6 & 12,3 & 3,3 & 13,3 & 3,3 & 7,0 & NA \\
\hline & & 2 & 12,3 & 3,0 & 13,5 & 3,2 & 6,0 & NA \\
\hline \multirow[t]{2}{*}{ Lugworm } & Head & 5 & 12,4 & 4,7 & 11,3 & 4,0 & 8,5 & NA \\
\hline & & 3 & 11,7 & 4,2 & 10,8 & 3,7 & 8,4 & NA \\
\hline Lugworm & Whole & 7 & 6,7 & 3,1 & 6,4 & 3,5 & 7,4 & NA \\
\hline
\end{tabular}


Table S2. Fatty acid composition, indicated by number of carbons and degree of unsaturation, of most abundant intact polar lipids (IPLs) in different aquatic species in this study. N.d. = not detected. PC:

Phosphatidycholine; PE: Phosphatidylethanolamine; MMPE: monomethyl-PE; PI: Phosphatidyinositol;

Plasmalogen: Fatty acid with vinyl linkage to glycerol backbone; Lyso: IPL where one fatty acid has been removed (lysed); Sphingo: Sphingobase. See Figure 3 for structures.

\begin{tabular}{|c|c|c|c|c|c|c|c|c|}
\hline & $\begin{array}{l}\text { Atlantic } \\
\text { muscle }\end{array}$ & $\begin{array}{l}\text { erring } \\
\text { gill }\end{array}$ & $\begin{array}{l}\text { Brown } \\
\text { muscle }\end{array}$ & $\begin{array}{l}\text { rout } \\
\text { gill }\end{array}$ & $\begin{array}{c}\text { Green shore crab } \\
\text { muscle }\end{array}$ & $\begin{array}{c}\text { Common } \\
\text { cockle } \\
\text { head }\end{array}$ & $\begin{array}{c}\text { Pacific } \\
\text { oyster } \\
\text { muscle }\end{array}$ & $\begin{array}{c}\text { Lugworm } \\
\text { muscle }\end{array}$ \\
\hline PC & $\begin{array}{l}38: 6 \\
34: 1\end{array}$ & $\begin{array}{l}34: 1 \\
32: 1 \\
40: 2\end{array}$ & $\begin{array}{l}38: 6 \\
36: 6 \\
34: 1\end{array}$ & $\begin{array}{l}34: 1 \\
32: 1 \\
36: 1 \\
36: 2\end{array}$ & $\begin{array}{l}34: 1 \\
32: 1\end{array}$ & $\begin{array}{l}36: 2 \\
34: 1 \\
32: 0 \\
32: 1 \\
34: 2\end{array}$ & $\begin{array}{c}38: 4- \\
38: 6 \\
36: 6 \\
32: 1 \\
37: 5\end{array}$ & $\begin{array}{l}34: 1 \\
36: 5 \\
32: 0 \\
32: 1 \\
30: 0\end{array}$ \\
\hline Plasmalogen-PC & n.d. & $34: 0$ & $38: 5$ & $\begin{array}{l}34: 0 \\
36: 0\end{array}$ & $\begin{array}{l}36: 3 \\
32: 0 \\
38: 4 \\
40: 5\end{array}$ & n.d. & n.d. & n.d. \\
\hline Lyso-PC & $\begin{array}{l}15: 0 \\
19: 1 \\
15: 0\end{array}$ & $17: 0$ & $\begin{array}{l}15: 0 \\
17: 1 \\
21: 6\end{array}$ & $\begin{array}{l}15: 0 \\
17: 0 \\
16: 3\end{array}$ & $\begin{array}{l}17: 1 \\
15: 0 \\
16: 0\end{array}$ & $\begin{array}{l}17: 1 \\
15: 0 \\
15: 1 \\
16: 1 \\
14: 0\end{array}$ & $\begin{array}{l}21: 6 \\
15: 0 \\
20: 5 \\
17: 0 \\
15: 0\end{array}$ & $\begin{array}{l}19: 1 \\
15: 0 \\
17: 1 \\
13: 0\end{array}$ \\
\hline Sphingo-PC & n.d. & n.d. & $42: 2$ & $\begin{array}{l}42: 2 \\
34: 1 \\
32: 1\end{array}$ & $\begin{array}{l}32: 1 \\
34: 1 \\
36: 1\end{array}$ & n.d. & n.d. & n.d. \\
\hline PE & n.d. & n.d. & n.d. & n.d. & $\begin{array}{l}38: 5 \\
38: 6\end{array}$ & n.d. & $\begin{array}{l}38: 3 \\
38: 4 \\
40: 5\end{array}$ & $40: 3$ \\
\hline MMPE & n.d. & n.d. & n.d. & n.d. & n.d. & n.d. & $38: 3$ & \\
\hline Betaine & n.d. & n.d. & n.d. & n.d. & n.d. & n.d. & $32: 1$ & n.d. \\
\hline $\mathbf{P I}$ & n.d. & n.d. & $41: 4$ & n.d. & n.d. & $36: 6$ & n.d. & n.d. \\
\hline
\end{tabular}

